\title{
Centre of Accreditation and Recognition of Excellence (CARE): Managing Scope of Technical and Vocational Education and Training (TVET) Courses towards Industrial- Based Recognition
}

\author{
Asymal Wajdi Muhd Akhir ${ }^{1}$, Syuhaida Ismail ${ }^{2}$, Mohd. Syazli Fathi ${ }^{3}$, Shamsul Sarip ${ }^{4}$ \\ ${ }^{1,2,3,4}$ Universiti Teknologi Malaysia, Kuala Lumpur, Malaysia \\ ${ }^{1}$ Majlis Amanah Rakyat, Kuala Lumpur, Malaysia
}

Article History: Received: 10 November 2020; Revised: 12 January 2021; Accepted: 27 January 2021; Published online: 05 April 2021

\begin{abstract}
The problem of unemployed graduates or mismatch between jobs and qualifications is amongst the subject often discussed by the new graduates nowadays. employers argue that many graduates do not possess the sufficient experience, knowledge and skills applicable to industry requirements even if they have spent between three and five years on a degree or graduate diploma. With high competition between the young graduates and experienced workers as well as the limited job vacancies available due to the current economic downturn as a result of the covid-19 pandemic, majlis amanah rakyat (mara) thus took the initiative to develop the centre of accreditation and recognition of excellence (care) in providing technical and vocational education and training (tvet) courses to undergraduate students towards industrial-based recognition. This paper hence appraises the scope management of tvet courses offered by care in ensuring that mara inspiration can be successfully fulfilled whilst the aforementioned problems amongst the young graduates can be solved efficiently. The findings of this paper are expected to clarify the elements needed by other higher education institutions and industries in managing the scope of tvet courses to develop care with industry-based recognition added value.
\end{abstract}

Keywords: Scope management, Technical and Vocational Education and Training (TVET), industrial-based recognition, Centre of Accreditation and Recognition of Excellence (CARE), Majlis Amanah Rakyat (MARA)

\section{Introduction}

As a higher education institution, the production or graduation of students with sufficient knowledge up to the level of competencies required by the industry is very important. Graduates also need to have a balance between knowledge and skills that are particularly demanded by industry. This task is apparently challenging to Technical and Vocational Education and Training (TVET) institution, as their specific task is helping students to develop the technical and practical skills needed to improve their livelihood and to be competitive in today's everchanging world, whereby similar with other types of higher learning institution, the results are not only measurable at the end of the student study term, but should also be measured for each semester of the study. Therefore, one of critical success factors (CSF) of the TVET institution is to ensure that the academic programmes offered meet the requirements and demands of the industry, especially during the current era of COVID-19 outbreak.

Industry players are undeniably looking for fresh recruits with critical thinking skills and knowledge depth that are rooted from knowing not just how to execute a given task, but also the logic behind it. However, employers around the country typically believed there are insufficient knowledge and skill among the graduates, indicating that the higher learning institutions do not actually have ample incentives for students to acquire the labour market-critical skills. Therefore, TVET is created as a part of the higher education system implementer in Malaysia to deliver standard of service essential to the growth of the nation as it trains skilled human resources that can function for the future development of the nation (Ibrahim, Ab Rahman, \& Yasin, 2012).

TVET in Malaysia that emphasizes the industry-based skills approach is key to developing Malaysia into a high-income developed country by 2050. TVET plays a transformative role in generating highly skilled human capital and improving the competitiveness of the local workforce and the national economy. In fact, TVET is also able to produce the local workforce needed by industry and the country to cope with the 4.0 phenomenon of the Industrial Revolution.

Looking at the emerging importance of TVET especially during this COVID-19 outbreak that has devastating effects on the Malaysian economy, Majlis Amanah Rakyat (MARA) Technical and Vocational Division that is responsible for the development of TVET educational programmes in preparing students for occupations that are essential to the economic development of Malaysia is called to carry new substantial responsibilities. These include to introduce academic programmes, which are categorised into 12 different clusters gearing towards the students of the institutions under its purview, which are Kolej Kemahiran Tinggi MARA (KKTM), MARAJapan Industrial Institute (MJII) and Institut Kemahiran MARA (IKM) throughout the country. TVETMARA is 
composed of the Technical and Vocational Divisions of MARA, KKTM, MJII and IKM, where the Centre for Accreditation and Recognition of Excellence (CARE) is established under TVETMARA in offering academic courses recognised by the industry (Akhir, Sarip, \& Fatah, 2020).

Therefore, this paper emerged with the aim in appraising the scopes of TVET courses offered by CARE to ensure that the industrial-based recognised graduates are able to be produced by CARE. To achieve this aim, the following objectives are outlined by this paper: (1) to discuss the overview of TVET in Malaysia; (2) to assess the evolution of CARE institutional development; and (3) to develop the scopes of industrial-based recognised TVET courses offered by CARE.

\section{Background}

Technical and Vocational Education Training (TVET) is a part of the higher education system implementer in Malaysia. Accreditation is a mechanism where the competency, authority or reputation credential is delivered. The accreditation process ensures that the certification processes are reasonable, hence they are typically eligible to audit and accept third parties, behaving in an ethical manner and implementing appropriate quality assurance (QA). The quality of service provided is vital to the development of nation, as it trains trained human capital that can work in the future (Ibrahim et al., 2012).

In Malaysia, accreditation is a formal recognition that a certificate, diploma or degree programme has attained the quality standards and criteria set by the Malaysian QA. In terms of accreditation, Malaysian education system has had two accreditation bodies: the Department of Skills Development (DSD), which accredits the skills sector and the Malaysian Qualifications Agency (MQA), a division within the Ministry of Education that accredits the vocational, technical and academic sectors. Engineering Technology Accreditation Council (ETAC) was appointed by the Government of Malaysia with an educational blueprint to ensure that all engineering and engineering technology diploma programmes offered in Malaysia comply with their standards (Abdullah et al., 2019 \& Islam et al. 2016).

It is ETAC pledge to all higher education stakeholders, namely students, parents and employers that the quality of an ETAC-accredited programme is assured accordingly (Engineering Technology Accreditation Council, 2019). In doing so, it is recognising the system for a number of purposes, which is often a foundation for certain parties. For example, this accreditation status would be used by the Public Service Department (PSD) to identify the qualification for public service jobs. An accredited centre by DSD usually means an organisation or place of work is approved by DSD. It provides the Malaysian Skills Certification applicants for participation and training in unique area based on the standards from National Occupational Skills Standard (NOSS) with expertise level from the Malaysian Skills Certificate or SKM to Malaysian Skills Advanced Diploma or DLKM (Ismail \& Abiddin, 2014).

As an initiative under the 11th Malaysia Plan (11MP), a Single Quality Assurance Framework for TVET is proposed, aimed at enhancing the quality of TVET students, increasing the standard of TVET and ultimately, mainstreaming TVET pathways comparable to academic pathways, in order to meet the job needs of the Malaysian industries. The MQA from Ministry of Education and the DSD from Ministry of Human Resources are working together to run this programme in an integrated way. To be more robust and reliable, the initiative aimed to improve the accreditation framework for TVET programmes. The initiative to harmonise and unify different QA systems into a single QA framework started with the Malaysian Qualifications Framework (MQF) reform, in which the skills sector and the vocational and technical sector were integrated into the TVET sector. The TVET Programme Accreditation Code of Practice (COPTPA) hence had been outlined in order to operationalise the single QA system of the TVET programme. Consequently, COPTPA has been used as the main reference for TVET accreditation. The scope of TVET Standards in COPTPA covers qualifications from level 1 to level 5 of the MQF (MQA, 2019).

\subsection{Evolution of the Centre for Accreditation and Recognition of Excellence (CARE)}

Each graduates need to have job competencies and skills for them to be competitive in the job market. Having a high degree is not a guarantee for a graduate to get a job. Instead, graduates must have appropriate and up to date knowledge, practical experience, soft skills and a positive attitude to complete them before they meet the challenges of the real world of employment. The framework for centre of accreditation and recognition excellence (care) with industry-based recognition will develop to meet the needs and demands of the industry in order to increase the marketability of graduates. 
The aim of the CARE introduced by Technical and Vocational Education Training Majlis Amanah Rakyat (TVETMARA) is to ensure that the graduates of TVETMARA have a high marketability to meet the industrial needs and opportunities to pursue their studies at a higher level in local educational institutions as well as abroad and to be able to enter the global labour market (globally competent workforce). Outcomes of CARE for TVETMARA graduates are highly skilled or competent, high employability, high market demand and high income

\subsection{Scope of Technical and Vocational Education and Training (TVET) Courses towards Industrial- Based Recognition}

Brands have historically been regarded as "identifiers" that differentiate products or services from others. Brand is also a powerful differentiator. According to Bansal (2014), brand is a recognisable mark, name or word associated with a product in a specific way that gives it a particular identity. Brands are used for business, marketing and advertising purposes. Melewar and Nguyen (2014) consider branding in higher education has been described as a key field of future brand theory and practice.

Hence, one of the scopes selected by Majlis Amanah Rakyat (MARA) in coming out with the Technical and Vocational Education and Training (TVET) courses at the Centre for Accreditation and Recognition of Excellence (CARE) that are recognised by the industry is by branding its services to potential students and industrial players. The first branding elements of Technical and Vocational Education and Training Majlis Amanah Rakyat (TVETMARA) are improvements to the Kolej Kemahiran Tinggi MARA (KKTM), MARAJapan Industrial Institute (MJII) and Institut Kemahiran MARA (IKM) logos. Logo redesigns and catchy slogans in internal branding are the fast fixes according to Whisman (2009).

Subsequently, MARA manages this TVET courses scope by coming out with the tagline "Talent Building, Generating Future" as a part of its TVETMARA branding. Subsequent flags, posters, presentation templates, video and web preparation guidelines are adjusted to strengthen the branding elements for TVETMARA. Referring to Saleem Fathima and Iglesias (2016), the co-creation of brands in internal branding is critical, where the purpose of internal branding is to allow employees to co-create brand values with different stakeholders. Internal branding is rooted in corporate marketing, which is focused on the idea of the employee as a customer. The idea of internal branding is also closely related, but separate, to that of employer branding. Therefore, it is clear that internal branding plays a critical role in the sense of higher education brand marketing strategy (Clark, Chapleo, \& Suomi, 2019), including TVETMARA who includes this as a part of its TVET courses scope management. This is further supported by other researchers (Balaji, Roy, \& Sadeque, 2016), who claimed that the personality of the higher education brand has a positive effect on the identity of higher education itself. Intangible factors such as the quality of the education it imparts, its faculty, community and services available to students determine a brand name for educational institutions. Thus, putting in mind that if TVETMARA wants to be reputed, they have to think about issues of proper accreditation and affiliation, followed with industry linkage towards industrial-based recognised TVET courses.

Talent pool is one of the attributes that is commonly used to characterise talent management. In TVETMARA, the Quadrant Method talent pool was chosen to choose the right person for a certain post, hence is included as a part of scope management of the TVET courses offered at CARE. Figure 1 illustrates the interaction between the two vacancy risk factors in four quadrants.

Positions with the highest vacancy frequency are put in the top right of the matrix. This quadrant encompasses high-quality positions with substantial market effect, important to the organisation and often difficult to fill in the labour marketplace. The lower right quadrants report positions, which are hard to fill but have little market impact added value. Such positions may involve highly qualified experts who do not directly influence customers. In the top left quadrant are located positions that are easy to fill and have a high market impact. These positions should be differentiated to give the company a competitive advantage. In the lower left portion of the matrix, positions are those with no added value and are easy to fulfil. In terms of vacancy risk analyses, such positions are not of great concern (Hatum, 2010). The organisation will certainly pay special attention to the most talented. For workers who are already hired, the management of the company must perform an appraisal and collect data on the abilities of each employee. A database of candidate profiles will be given for the promotion process in TVETMARA. It all ends with a common objective of having the best talent to fill the role needed to push TVETMARA towards industry-based recognition. 


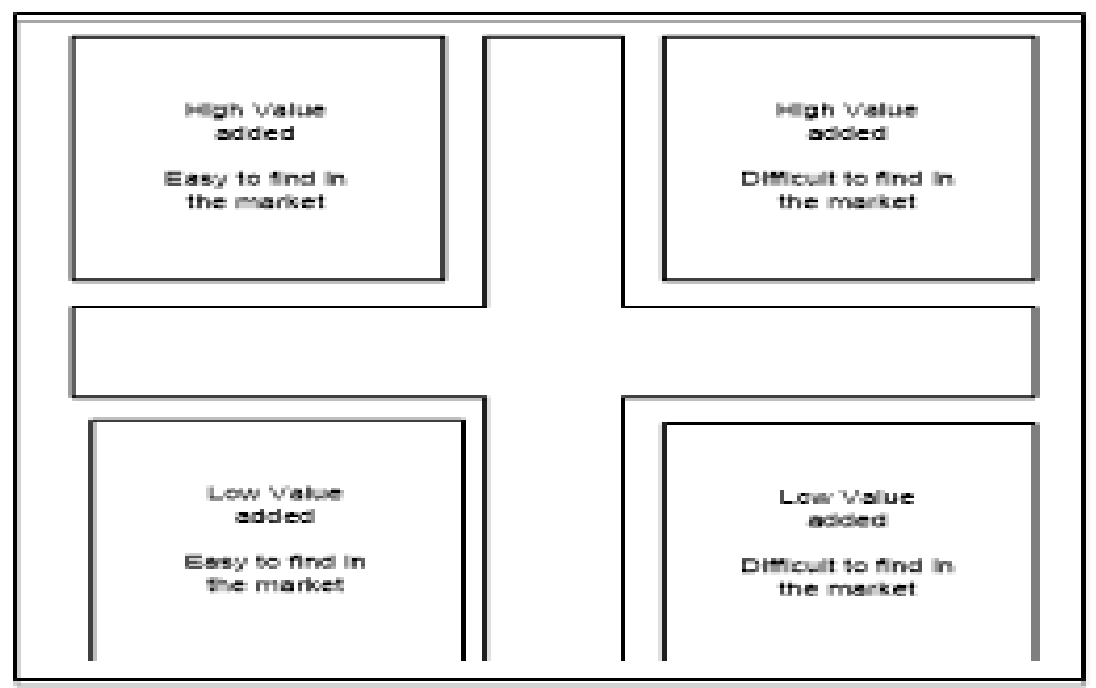

Figure 1. Risk of position vacancy

According to Iles, Preece, and Chuai (2010), if organisations like TVETMARA want to strive to thrive, deliver quality and do their best to recognise, attract and deploy their talent in a way called talent development (TD). Through developing talent of employees, TVETMARA would be able to build their internal talent to meet the future expertise needs. This could be stated that development of organisational talent is not feasible at work without the development of talent at the level of the individual employees. They will both be addressed together because each of them support each other (Gallardo-Gallardo, Dries, \& González-Cruz, 2013). Conjoint conceptualisation of the individual and organizational needs is therefore essential and included as a part of scope management of the TVET courses offered at CARE. Organisations that are mindful of their abilities of employees are taking a more comprehensive approach to developing an environment and learning opportunities that meet the needs of organisational talent (Garavan, Carbery, \& Rock, 2012). The effect of environmental factors is significant, as it affects not only the TD but also the intra-personal influence of the trigger. This can demotivate the employee and adversely influence motivation for continuing growth efforts when the employee acquires and develops new qualifications without any gain for the employee (Khalid, 2018).

Employer confidence in hiring employees who come from accredited institutions. Since accreditation status is critical for employers when evaluating qualifications of job applicants and when deciding to provide support to current workers pursuing further education, TVETMARA has included accreditation as a part of scope management of the TVET courses offered at CARE. TVET institutions have demonstrated improvement along with key criteria and this confirms the positive impact of accreditation on the quality improvement of services in TVET institutions. Such findings have guided TVETMARA stance and belief in using accreditation as an important tool for improving quality at TVETMARA. Accreditation by Asia Pacific Accreditation and Certification Commission Recognition (APACC), an internationally recognised quality mark is amongst the accreditations relevant to TVETMARA. APACC aims to accredit and certify TVET institutions for the development of human resources through standardisation and harmonisation of education and training systems that will facilitate the mobility of workers across national borders in Asia and the Pacific region by providing accreditations such as gold, silver and bronze (Kulanthaivel). In TVETMARA, three institutions were accredited by APACC with gold accreditation, namely MJII, KKTM Kuantan and KKTM Ledang, whilst the remaining 22 TVET institutes are currently in the process of gaining APACC.

Another important scope of the TVET courses offered at CARE towards industrial-based recognition is the Industrial Revolution 4.0 (IR 4.0) set of skills required for each TVET courses. Understanding that keeping a company competitive for the coming year can only be achieved if they have a highly skill workforce in the company (Rachford, 2015), TVETMARA places reactive urges for rapid training together with competence and skill data. In order to meet this challenge, it is necessary to identify the skills required and systematically assess the gaps (Guenther, 2004), thus become one of the scopes of the TVET courses offered at CARE. Since past studies by Makhbul and Yussof (2017) have shown that there is a skills gap needed by employers and graduates, the skills set for the programme have been identified on behalf of TVETMARA to be absorbed by the lecturers and students of the programme. For example, generic skills and personal skills for IR 4.0 are included in the syllabus to make the student more competitive hence being recognised by the industry. 
The implementation of constructive alignment in the CARE syllabus has been carried out in order to achieve industrial-based recognition. Constructive alignment is a teaching style that demonstrates explicitly before learning is carried out, what students are expected to learn and how their learning should be conveyed. Teaching is then designed to include students in learning experiences that maximise their chances of achieving these results, and evaluation tasks are designed to make clear decisions as to how well these results have been achieved (Kandlbinder, 2014). Since alignment happens when students are asked to participate in learning activities that help them develop the knowledge, skills and understandings planned for the unit and being assessed, constructive alignment in the CARE syllabus is seen as one of the scopes of the TVET courses. A constructively integrated unit capitalises on the positive impact of feedback on learning experiences of students. If evaluation enhances learning for students, then students can most likely achieve CARE desired outcomes if the evaluation is consistent with CARE intentions.

Malaysian Skill Competition is a national skills competition organised to select and recognise young people and skilled workers who have superior skills and the opportunity to represent Malaysia at the ASEAN Skills Competition (ASC) and World Skills Competition (WSC) following the screening and evaluation process established by the Department of Skills Development (DSD) and the Ministry of Works (MOW). Then, Malaysia World Skill Malaysia Instructor is a competition for skills to enhance competency and competitiveness among the instructors of public, private and industrial training institutions. With this competition, instructors can compete in a healthy way to demonstrate the skills they have as well as the recognition and rewards offered. Referring to Tavakoli, Karimi, and Salimi (2014), the results of the analysis and the experience of the role of competitions in the development and promotion of technical and vocational training can not be ignored hence included as one of the scopes of the TVET courses offered at CARE. When the skills set of IR 4.0 and constructive alignment are integrated into the CARE syllabus, the next focus is to analyse the gap between the CARE lecturers and the syllabus. A workshop with the World Skill Chief Judge will be held to analyse the syllabus that has been developed with the needs of the World Skills Competition. The objective of this workshop is to reduce the gap between the program and the instructor. If the teacher is great, then the great students are born. The name of an institution will be raised by the great teachers and students who win the competition. Industry shall recognise the educational output of the institution.

Once the great students are born, the next focus for industry-based recognition is the concept of training, hence included as one of the scopes of the TVET courses at CARE. In TVETMARA, industrial-based education and training (IBET) is integrated in all programmes of the diploma course. The IBET concept is that students do real work in the industry while they are still in college. For an example, most of the polytechnics and higher education activities in Indonesia are carried out in some way separately from industry and independently, thus industry is facing difficulties to understand and respond directly to technical developments in polytechnics and higher education. They improve it by adding a production job (a real order from industry) into practice programme and strengthen it by removing the standardised activities without losing the complexity of the curriculum-oriented skills and information (Ilyas \& Semiawan, 2017).

The next scope of the TVET courses at CARE is the Teaching Factory model. The Teaching Factory model attempts to match the teaching and training of manufacturing with the needs of current industrial practice. To cope with the growing industrial requirements of the factories of the potential, potential engineers and technical workers need to be trained with new curriculums. The model for Teaching Factory involves the required educational approach and the requisite Information and Communication Technology (ICT) configuration to promote interaction between industry and academia. The Teaching Factory aims at a two-way exchange of information between academia and industry. In the context of TVETMARA, both knowledge sources of the model are discussed inside real-life industrial applications. The Teaching Factory model provides the students and research engineers with a real-life setting to improve their skills and appreciate the difficulties involved in daily industrial practice (Chryssolouris, Mavrikios, \& Rentzos, 2016), hence has been integrated into the TVETMARA curricula. TVETMARA has collaborated with Composite Technology \& Research Company Malaysia (CTRM) since 2013 to supply workforce in the aerospace industry complying strictly to the Aerospace Blueprint 2030. The purpose of the collaboration is to introduce the lecturers to new knowledge important for the research and manufacture of industrial aerospace products. The Teaching Factory concept used has become a value added to the institution for the empowerment of technical and vocational education. This training approach enhances knowledge in the creation of product transformation and materials that are beneficial to local and international markets. Since Teaching Factory is one of the important scopes of the TVET courses at CARE, it will be extended to all TVETMARA programmes. 


\section{Methodology}

The research approach was conducted by secondary data collection via analysis of literature and documents. Searching literature includes reviewing materials including internal system documentation, on-line repositories and other related lifetime publications.

\section{Result and Discussion}

In order to successfully address the scope management of Technical and Vocational Education and Training (TVET) courses at the Centre of Accreditation and Recognition of Excellence (CARE) towards producing industrial-based recognition graduates, 8 important scopes of TVET courses at CARE were highlighted in this paper. Each element has its own unique way of driving CARE for recognition by the industrial players. Starting with the branding of Technical and Vocational Education and Training Majlis Amanah Rakyat (TVETMARA) and the "Talent Building, Generating Future" tagline, TVETMARA places an emphasize on the scope of promotion process for selecting the best talent using the quadrant method to push TVETMARA towards industry-based recognition. APACC Gold Level accreditation in order to improve the quality of TVETMARA followed with the Industrial Revolution 4.0 (IR 4.0) skills set for every diploma programme in TVETMARA for instructor and student are also included as amongst the important scopes in TVET courses at CARE. Implementing constructive alignment within the CARE syllabus to maximise the positive effect of feedback on student learning experiences and winning skills competition to earn industry-based recognition are also substantial. By incorporating the concept of industrial-based education and training (IBET) into the curriculum, students are expected to obtain real industry experience, hence being included as one of the important scopes of the TVET courses at CARE. Lastly, the idea of adoption of Teaching Factory is seen as an added benefit to the CARE for motivating technical and vocational education via its TVET courses.

\section{Conclusion}

This paper has successfully fulfilled its aim of appraising the scope management of Technical and Vocational Education Training (TVET) courses at the Centre of Accreditation and Recognition of Excellence (CARE) towards obtaining industrial-based recognition. Through this paper, TVETMARA will be recognised for producing graduates who have their own skills set as required by the industry. The industry no longer needs to train its workers because the graduates of TVETMARA already have the skills they need and at the same time this will open up a wider job opportunity to for them. In addition, CARE would strengthen the collaboration between TVETMARA and the industries whereby TVETMARA graduates are able to demand higher salaries. With CARE, implementation of IBET in TVETMARA will also be improved.

\section{Acknowledgements}

The authors would like to express their sincere gratitude to the Ministry of Education Malaysia, Universiti Teknologi Malaysia (UTM) and the Research Management Centre (RMC) for providing the financial support for this paper to be published. This study is financed by Razak Faculty of Technology and Informatics (FTIR).

\section{References}

1. Abdullah, M. F., Mokhtar, N. F., Darus, R., Jamaludin, N. F., Fauzi, N. A., Ali, Y. M., \& Ismail, N. (2019). Syllabus review procedures and implementation toward practical based oriented Teaching and Learning (TnL). Paper presented at the 2019 IEEE 11th International Conference on Engineering Education (ICEED).

2. Akhir, A. W. M., Sarip, S., \& Fatah, A. Y. A. (2020). Strategy to develop centre of accreditation of excellence (CARE) with industrial-based recognition. International Journal of Emerging Trends in Engineering Research, 8(1 Special Issue 1), 27-35. doi:10.30534/ijeter/2020/0581.12020

3. Balaji, M., Roy, S. K., \& Sadeque, S. (2016). Antecedents and consequences of university brand identification. Journal of Business Research, 69(8), 3023-3032.

4. Bansal, S. (2014). Branding an Academic Institute:The Strategic Issues. JOURNAL OF INTERNATIONAL ACADEMIC RESEARCH FOR MULTIDISCIPLINARY 2320 5083, 2.

5. Chryssolouris, G., Mavrikios, D., \& Rentzos, L. (2016). The teaching factory: a manufacturing education paradigm. Procedia Cirp, 57, 44-48.

6. Clark, P., Chapleo, C., \& Suomi, K. (2019). Branding higher education: an exploration of the role of internal branding on middle management in a university rebrand. Tertiary Education and Management. doi:10.1007/s11233-019-09054-9 
7. Engineering Technology Accreditation Council, E. (2019). Engineering Technician Education Programme Accreditation Standard 2019.

8. Gallardo-Gallardo, E., Dries, N., \& González-Cruz, T. F. (2013). What is the meaning of 'talent' in the world of work? Human Resource Management Review, 23(4), $290 \quad-\quad 300$. doi:https://doi.org/10.1016/j.hrmr.2013.05.002

9. Garavan, T., Carbery, R., \& Rock, A. (2012). Mapping talent development: Definition, scope and architecture. European Journal of Training and Development, 36, 5-24. doi:10.1108/03090591211192601

10. Guenther, G. A. (2004). Comprehensive curriculum management: taking a business engineering group from declining to emerging skill sets-a holistic approach. Paper presented at the 2004 IEEE/UT Engineering Management Conference.

11. Hatum, A. (2010). Next Generation Talent Management.

12. Ibrahim, M. Z., Ab Rahman, M. N., \& Yasin, R. M. (2012). Assessing students perceptions of service quality in technical educational and vocational training (TEVT) institution in Malaysia. Procedia-Social and Behavioral Sciences, 56, 272-283.

13. Iles, P., Preece, D., \& Chuai, X. (2010). Talent management as a management fashion in HRD: Towards a research agenda. Human Resource Development International, 13, 125-145. doi:10.1080/13678861003703666

14. Ilyas, I. P., \& Semiawan, T. (2017). Industrial-Based Learning (IBL): Promoting Excellent on Polytechnics and Vocational Higher Education. Bussiness, Management, Accounting, Taxation, and Economics Studies (BMATES), 513.

15. Ismail, A., \& Abiddin, N. Z. (2014). Issues and challenges of technical and vocational education and training in Malaysia towards human capital development. Middle-East Journal of Scientific Research, 19(2), 7-11.

16. Islam, R., Ghani, A.B.A., Kusuma, B., Theseira, B.B. (2016). Education and human capital effect on Malaysian economic growth. International Journal of Economics and Financial Issues, 6 (4), pp. 17221728.

17. Kandlbinder, P. (2014). Constructive alignment in university teaching. HERDSA News, 36(3), 5.

18. Khalid, F. (2018). The Choreography of Talent Development in Higher Education. Higher Education Studies, 9, 40. doi:10.5539/hes.v9n1p40

19. Kulanthaivel, G. Asia Pacific Accreditation and Certification Commission (APACC) Certification for TVET Institutions.

20. Makhbul, Z. M., \& Yussof, I. (2017). Antara realiti dan harapan-Kajian empirikal persepsi majikan terhadap prestasi graduan tempatan (Between reality and expectation-An empirical study of employers' perceptions of the performance of Malaysian local graduates). Geografia-Malaysian Journal of Society and Space, 11(10).

21. Melewar, T. C., \& Nguyen, B. (2014). Five areas to advance branding theory and practice. Journal of Brand Management, 21(9), 758-769. doi:10.1057/bm.2014.31

22. MQA. (2019). Code of Practice for TVET Programme Accreditation (COPTPA) (Vol. 2020): Malaysian Qualifications Agency.

23. Rachford, J. (2015). Qualified people-It is all about the skill sets. Paper presented at the 2015 IEEE IAS Electrical Safety Workshop.

24. Saleem Fathima, Z., \& Iglesias, O. (2016). Mapping the domain of the fragmented field of internal branding. Journal of Product \&amp; Brand Management, 25(1), 43-57. doi:10.1108/JPBM-11-20140751

25. Tavakoli, G. A., Karimi, A., \& Salimi, M. (2014). Vocational Skill Competition, A Mechanism to Develop Technical and Vocational Training.

26. Whisman, R. (2009). Internal branding: a university's most valuable intangible asset. Journal of Product \&amp; Brand Management, 18(5), 367-370. doi:10.1108/10610420910981846 